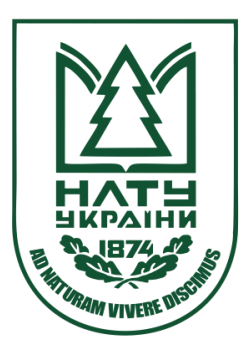

Науковий вісник НлТУ України

Scientific Bulletin of UNFU

(C)

ISSN 1994-7836 (print)

https://nv.nltu.edu.ua

https://doi.org/10.36930/40290913

$@ \bowtie$ Correspondence author

Article received 13.11.2019 p.

Article accepted 26.12.2019 p.

V. V. Melnyk

UDK 574:630*18(477.42)

В. В. Мельник', Т. В. Курбет', А. Р. Максимчук', О. В. Висоцький1, З. М. Шелест1, І. В. Давидова' , О. В. Зборовська²

${ }^{1}$ Держсавний університет "Житомирська політехніка", м. Житомир, Украйна

${ }^{2}$ Поліський філіал УкрНДІЛГА ім. Г. М. Висоиького, с. Довжик, Украйна

\title{
ДИНАМІКА РАДІОАКТИВНОГО ЗАБРУДНЕННЯ ЗЕЛЕНИХ МОХІВ В УМОВАХ СВІЖОГО БОРУ У ЛІСАХ ЖИТОМИРСЬКОГО ПОЛІССЯ
}

\begin{abstract}
Досліджено зміну вмісту радіонуклідів у фітомасі зелених (брієвих) мохів в умовах свіжого бору Українського Полісся впродовж 2016-2018 рр. Середня щільність радіоактивного забруднення грунту на пробній площі становила $199^{ \pm 52}$ кБк/м². З'ясовано, що величини питомої активності та інтенсивності надходження радіонуклідів до фітомаси аналізованих видів мали значні коливання. Вміст радіонукліду у фітомасі дикрану багатоніжкового за період спостережень зменшився в 1,3 раза, а для плевроцію Шребера подібне зменшення становило 1,2 раза. Виявлено, що дикран багатоніжковий характеризується більшими величинами концентрації ${ }^{137} \mathrm{Cs}$ порівняно $з$ плевроцієм Шребера, в середньому - в 1,5 раза за досліджуваний період. Відзначено загальну закономірність щодо розподілу вмісту ${ }^{137} \mathrm{Cs}$ за фракціями зелених мохів. За величиною радіоактивного забруднення фракції моху можна розмістити у вигляді такого ряду: очос > жива фракція > мертва фракція. Упродовж трьох років спостережень середній вміст ${ }^{137} \mathrm{Cs}$ в очосі верхоплідного та бокоплідного мохів зменшився в 1,4 та 1,2 раза відповідно, а для живої та мертвої фракцій таке зменшення становило 1,3 раза. Інтенсивність надходження радіонуклідів до фітомаси плевроцію Шребера в 1,4 раза менша порівняно з дикраном багатоніжковим. Виявлено тенденцію до зниження значень коефіцієнта переходу ${ }^{137} \mathrm{Cs}$, як до фітомаси загалом, так і до окремих фракцій обох досліджуваних видів моху.
\end{abstract}

Ключові слова: питома активність; ${ }^{177} \mathrm{Cs}$; інтенсивність надходження радіонуклідів; фракції моху.

Вступ. Після аварії на ЧАЕС значна площа України зазнала радіоактивного забруднення. Найбільш радіоактивно забрудненими виявилися лісові масиви. Внаслідок первинного накопичення радіонуклідів у лісових екосистемах Українського Полісся виникла потреба проведення досліджень з вивчення інтенсивності надходження та особливостей перерозподілу радіонуклідів між компонентами цих екосистем. Мохоподібні відіграють важливу роль у процесі міграції радіоактивних елементів до компонентів лісових екосистем, що зумовлено їх анатомо-морфологічними особливостями.

Враховуючи той факт, що останні дослідження радіоактивного забруднення мохів проводили наприкінці 90-х років, актуальним стає встановлення сучасного вмісту радіонуклідів у фітомасі мохового покриву у лісах Житомирського Полісся, завдяки чому буде доповнено наукові уявлення щодо розподілу ${ }^{137} \mathrm{Cs}$ у компо- нентах лісових екосистем регіону досліджень.

Аналіз літературних джерел. Відомо, що мохи інтенсивніше накопичують радіонукліди порівняно зі судинними рослинами (Dragovic et al., 2010; Reimann et al., 2008; Schröder et al., 2008). За деякими даними, відносна ефективність накопичення ${ }^{137} \mathrm{Cs}$ живими мохами на порядок перевищує таке у продуктах метаболізму (опале листя) та плодах деревних рослин (білої акації та липи) (Gudzenko, 2007). Надходження радіонуклідів до фітомаси мохів відбувається двома основними шляхами: за допомогою атмосферних випадінь та проникненням через кореневу систему (Bolukh, 1994; Popovic et al., 2010; Nifontova, 2006). Для мохоподібних відзначено високу поглинальну здатність та міцну фіксацію радіоактивних елементів, а також для них характерним $€$ довготривалий життєвий цикл розвитку. Виявлено, що мохоподібні утворюють суцільні покриття, внаслідок

Інформація про авторів:

Мельник Вікторія Вікторівна, здобувач, кафедра екологіï. Email: melnyk_vika91@ukr.net; https://orcid.org/0000-0002-3551-5085

Курбет Тетяна Володимирівна, канд. с.-г. наук, доцент, кафедра екологіï. Email: meraviglia@ukr.net; https://orcid.org/0000-0001-7820-4263

Максимчук Анастасія Русланівна, магістрант, кафедра екологіï. Email: nastya.maksimchuk@gmail.com

Висоцький Олександр Володимирович, магістрант, кафедра екології. Email: oleksandr.visotskii@gmail.com

Шелест Зоя Михайлівна, канд. біол. наук, доцент, кафедра екології. Email: szm05121960@gmail.com

Давидова Ірина Володимирівна, канд. с.-г. наук, доцент, кафедра екологіï. Email: davydvairina2@gmail.com; https://orcid.org/0000-0001-6535-3948

зборовська Ольга Володимирівна, ст. наук. співробітник, відділ радіаційної екології лісу. Email: olga.zborovska@ukr.net; https://orcid.org/0000-0003-1649-0297

Цитування за ДСтУ: Мельник В. В., Курбет Т. В., Максимчук А. Р., Висоцький О. В., Шелест З. М., Давидова І. В., Зборовська О. В. Динаміка радіоактивного забруднення зелених мохів в умовах свіжого бору у лісах Житомирського Полісся. Науковий вісник НлТУ України. 2019, т. 29, № 9. С. 76-80.

Citation APA: Melnyk, V. V., Kurbet, T. V., Maksymchuk, A. R., Vysotskiy, O. V., Shelest, Z. M., Davydova, I. V., \& Zborovska, O. V. (2019). Dynamics of radioactive contamination of green mosses in fresh pine forest of Zytomyr Polissya. Scientific Bulletin of UNFU, 29(9), 76-80. https://doi.org/10.36930/40290913 
чого утримують значну частку радіонуклідів та сприяють включенню їх у біологічний кругообіг екосистеми (Bolukh \& Virchenko, 1994; Kulikov \& Bochenina, 1976; Kulikov \& Molchanova, 1990). З'ясовано, що накопичення радіонуклідів окремими видами мохів залежить як від морфологічних, так і фізіологічних особливостей виду. Так, особливого вивчення щодо розподілу та накопичення радіонуклідів потребують два підкласи сфагнові та зелені мохи.

Мохоподібні мають значне поширення у лісових екосистемах, проте сфагнові мохи найчастіше трапляються на перезволоженій місцевості (лісові болота), а зелені мохи - у суходільних лісах. Закономірності накопичення та розподілу радіонуклідів за фракціями різних видів мохів істотно відрізняються. Сфагнові мохи поглинають поживні елементи та радіонукліди 3 водних розчинів, що надходять 3 аеральними випадіннями. За рахунок значного перезволоження спостерігається глибока міграція радіонуклідів по товщі моху та торфу. Мертва фракція сфагнового покриву $є$ своєрідним субстратом для живої фракції, що призводить до замкнутої циклічності руху радіонуклідів між ними та унеможливлює проникнення радіоактивних елементів до судинних рослин (Kulikov \& Molchanova, 1990).

Зелені мохи є найпоширенішими у лісах Українського Полісся, а основними їх представниками $є$ дикран багатоніжковий та плевроцій Шребера. На сьогодні, немає єдності суджень учених щодо інтенсивності надходження радіонуклідів до бокоплідних та верхоплідних мохів (Bolukh \& Virchenko, 1994; Virchenko \& Bolyukh, 1993). З'ясовано, що зелені мохи інтенсивніше поглинають ${ }^{137} \mathrm{Cs}$ порівняно $3{ }^{90} \mathrm{Sr}$, а максимальний вміст радіонукліду зосереджується у наростаючій фракції моху (Dragovic et al., 2010; Nifontova,1995). Більшість дослідників зазначають, що фракції моху за вмістом ${ }^{137} \mathrm{Cs}$ можна подати у такому ранжованому ряді: очос > жива фракція > мертва фракція (Bolukh \& Virchenko, 1994; Virchenko \& Bolyukh, 1993; Melnyk \& Kurbet, 2018). Дослідники з'ясували, що брієві мохи інтенсивніше накопичують радіоактивні елементи, ніж сфагнові (Molchanova \& Bochenina, 1980; Dragovic et al., 2010; Nifontova, 1995; Mihailovic \& Gajic, 2010). Аналізуючи значення коефіцієнтів переходу та величин вмісту ${ }^{137} \mathrm{Cs}$ у фітомасі мохів, їх можна подати у такому вигляді: сфагнові мохи < бокоплідні брієві мохи < верхоплідні брієві мохи (Bolukh, 1994; Bolukh \& Virchenko, 1994). Про особливості накопичення радіонуклідів різними мохоподібними в різних типах екосистем, про міграцію та нагромадження радіонуклідів у різних частинах тіла мохів, про використання мохоподібних як індикаторів накопичення радіонуклідів, для використання їх як тест-об'єктів з метою оцінювання та прогнозування радіоекологічної обстановки території йдеться у багатьох працях (Bolukh, 1994; Grodzinsky, 1959; Mokronosov \& Kulikov, 1988; Molchanova \& Bochenina, 1980; Nifontova, 1995). Загалом аналіз літературних джерел виявив недостатню кількість публікацій щодо сучасних рівнів радіоактивного забруднення мохового покриву.

Об'єкт дослідження - зелені мохи, що зростають у свіжих борах Українського Полісся.

Предмет дослідження - динаміка радіоактивного забруднення фітомаси зелених мохів.
Мета дослідження - встановити вміст та інтенсивність надходження ${ }^{137} \mathrm{Cs}$ до представників верхоплідних та бокоплідних мохів та їх окремих фракцій.

Завдання дослідження - проаналізувати динаміку радіоактивного забруднення зелених мохів у свіжих борах Українського Полісся.

Матеріали та методи дослідження. Закономірності радіоактивного забруднення надземної фітомаси мохів у свіжих борах Українського Полісся вивчали на прикладі таких видів: дикрану багатоніжкового (Dicranum polysetum Sw.) та плевроцію Шребера (Pleurozium schreberi (Willd. Ex Brid.) Mitt.). Дослідження проводили у 2016-2018 рр. у Житомирському Поліссі на пробній площі, розташованій у Народицькому лісництві ДП "Народицьке спеціалізоване лісове господарство". Закладку пробної площі $(100 \times 100$ м) здійснювалася за стандартною методикою: було закладено 10 облікових ділянок (по $1 \mathrm{~m}^{2}$ ), 3 кожної з них відбирали зразки фітомаси брієвих мохів. Після відбору зразків моху здійснювали поділ фітомаси на фракції: верхівкову (живу), середню (мертву) та нижню (очос). Відповідні зразки грунту відбирали методом конверту на глибину 20 см, за допомогою спеціального бура. Перед вимірюванням питомої активності радіонуклідів на сцинтиляційному гамма-спектрометрометричному приладі (GDM-20), усі зразки пройшли підготовчі етапи для проведення аналізу. Статистичний аналіз результатів вимірювань проводили 3 використанням прикладного пакету програм Microsoft Excel.

Результати дослідження та їх обговорення. Рівень радіоактивного забруднення території на пробній площі мав досить широку амплітуду коливання - від 167 до

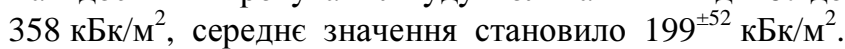
Аналізуючи величини питомої активності ${ }^{137} \mathrm{Cs}$ у фітомасі дикрана багатоніжкового та плевроція Шребера протягом років спостережень, відзначено зменшення вмісту радіонукліда (рис. 1). Так, у 2016 р. середній вміст ${ }^{137} \mathrm{Cs}$ у фітомасі дикрану багатоніжкового становив $12818^{ \pm 394}$ Бк/кг, що є найвищим значенням за період спостереження. У 2017 р. вміст ${ }^{137}$ Cs у фітомасі дикрану багатоніжкового знизився в 1,1 раза, а у 2018 р. - в 1,3 раза порівняно 32016 р. Достовірність отриманих результатів підтверджено критерієм Фішера: 20162017 pp. $-F_{\text {факт. }}=6,5>F_{(1 ; 40 ; 0,95)}=4,1 ; 2017-2018$ pp. $F_{\text {факт. }}=29,0>F_{(1 ; 44 ; 0,95)}=4,1 ; 2016-2018$ pp. $-F_{\text {факт. }}=$ $59,3>F_{(1 ; 42 ; 0,95)}=4,1$. Для плевроцію Шребера середнє значення концентрації ${ }^{137} \mathrm{Cs}$ у 2016 р. становило $8769^{ \pm 194}$ Бк/кг, що в 1,1 та 1,2 раза менше порівняно 3 2017 та 2018 рр. спостережень відповідно, а вміст радіонукліду у 2017 р. був неістотно (у 1,1 рази) більшим, ніж у наступний рік. Достовірність отриманих результатів підтверджується критерієм Фішера за роками спостережень: 2016-2017 pp. $-F_{\text {факт. }}=7,7>F_{(1 ; 53 ; 0,95)}=$ 4,$0 ; 2017-2018$ pp. $-F_{\text {факт. }}=4,0>F_{(1 ; 48 ; 0,95)}=3,8 ; 2016$ 2018 pp. $-F_{\text {факт. }}=32,2>F_{(1 ; 55 ; 0,95)}=4,0$. Аналіз отриманих значень дає змогу стверджувати, що на пробній площі величини питомої активності ${ }^{137} \mathrm{Cs}$ у фітомасі дикрану багатоніжкового були вищими порівняно 3 плевроцієм Шребера: у 2016 та 2017 рр. - в 1,5 раза, а у 2018 р. - у 1,4 раза. Достовірність отриманих даних підтверджується коефіцієнтом Фішера на 95-ти \% довірчому рівні: 2016 р. $-F_{\text {факт. }}=104,5>F_{(1 ; 49 ; 0,95)}=4,0 ; 2017$ p. 
$-F_{\text {факт. }}=72,7>F_{(1 ; 44 ; 0,95)}=4,1 ; 2018$ p. $-F_{\text {факт. }}=$ $66,7>F_{(1 ; 48 ; 0,95)}=4,0$.

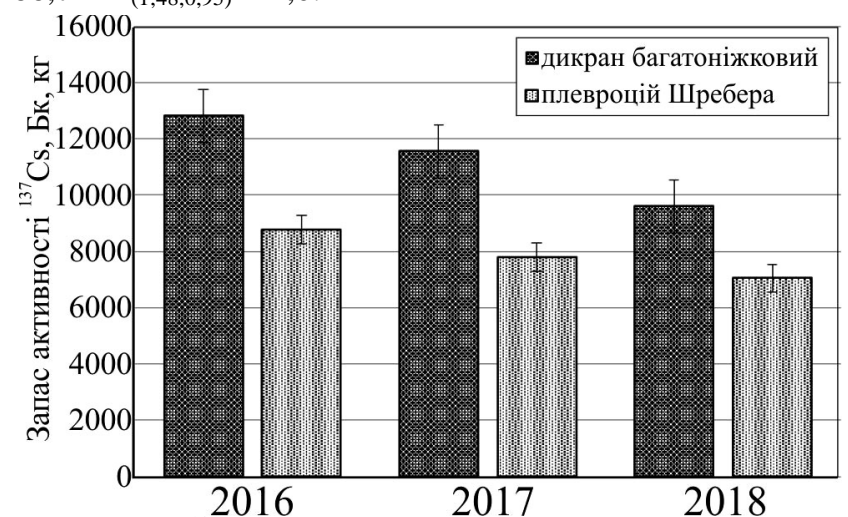

Рис. 1. Вміст ${ }^{137} \mathrm{Cs}$ у фітомасі брієвих мохів свіжого бору Українського Полісся у різні роки. Джерело: результати отримали автори

Ми також провели порівняльний аналіз розподілу вмісту радіонукліду у різних фракціях мохів (таблиця). Пофракційний аналіз концентрації ${ }^{137} \mathrm{Cs}$ у фітомасі дикрану багатоніжкового показав, що у 2016 р. найвище його значення відзначено в очосі i становить $14269^{ \pm 424}$ Бк/кг, що неістотно перевищує (в 1,1 раза) вміст ${ }^{137} \mathrm{Cs}$ у живій фракції. Мертва фракція містить ${ }^{137} \mathrm{Cs}$ в 1,3 та 1,2 раза менше порівняно 3 очосом та живою фракцією відповідно. У 2017 р. мінімальний вміст ${ }^{137} \mathrm{Cs}$ встановлено у мертвій фракції $\left(10390^{ \pm 308}\right.$ Бк/кг), що неістотно менше порівняно із живою фракцією моху. Проте очос накопичував в 1,3 та 1,2 раза більше ${ }^{137} \mathrm{Cs}$, ніж мертва та жива фракція відповідно.

Таблиця. Середні значення питомої активності ${ }^{137} \mathrm{Cs}$ у фракціях зелених мохів Українського Полісся (2016-2018 pp.)

\begin{tabular}{|c|c|c|c|c|c|c|}
\hline \multirow{2}{*}{$\begin{array}{c}\text { Рік спосте- } \\
\text { реження }\end{array}$} & \multicolumn{2}{|c|}{ Питома активність ${ }^{137}$ Сs у фракціях моху, Бк/кг } \\
\cline { 2 - 7 } & $M$ & $m$ & $M$ & $m$ & $M$ & $m$ \\
\hline \multicolumn{7}{|c|}{ Дикран багатоніжковий } \\
\hline 2016 & 12725 & 348 & 11006 & 228 & 14269 & 424 \\
\hline 2017 & 10800 & 414 & 10390 & 187 & 13005 & 308 \\
\hline 2018 & 9863 & 145 & 8433 & 241 & 10370 & 77 \\
\hline \multicolumn{7}{|c|}{ Плевроцій Шребера } \\
\hline 2016 & 8569 & 96 & 7795 & 161 & 9564 & 273 \\
\hline 2017 & 7036 & 464 & 6679 & 343 & 9183 & 278 \\
\hline 2018 & 6730 & 542 & 6189 & 327 & 7773 & 264 \\
\hline
\end{tabular}

Джерело: результати отримали автори.

Вивчаючи вміст ${ }^{137} \mathrm{Cs}$ у фітомасі дикрану впродовж 2018 р. встановлено, що жива фракція поглинає в 1,2 раза більше радіонуклідів, ніж мертва та неістотно менше порівняно $з$ очосом, який своєю чергою містить в 1,3 раза більше радіонуклідів, ніж мертва фракція. Загалом за період з 2016 по 2018 рp. середній вміст ${ }^{137} \mathrm{Cs}$ в очосі дикрану багатоніжкового зменшився в 1,4 раза, а для живої та мертвої фракцій таке зменшення становило 1,3 раза. Достовірність отриманих даних підтверджується однофакторним дисперсійним аналізом: для живої фракції $-F_{\text {факт. }}=21,5>F_{(2 ; 12 ; 0,95)}=3,9$; для мертвої фракції $-F_{\text {факт. }}=37,6>F_{(2 ; 20 ; 0,95)}=3,5$; для очосу $F_{\text {факт. }}=46,6>F_{(2 ; 25 ; 0,95)}=3,4$.

Розподіл величини питомої активності ${ }^{137} \mathrm{Cs}$ за фракціями плевроцію Шребера виявився аналогічним, як і у дикрану багатоніжкового. Так, у 2016 р. середнє значення питомої активності ${ }^{137} \mathrm{Cs}$ в його очосі дорівнювало $9564^{ \pm 273}$ Бк/кг, що в 1,2 раза більше, ніж у мертвій фракції. Для живої фракції плевроцію встановлено неістотно вище та нижче значення (в 1,1 раза) концентрації ${ }^{137} \mathrm{Cs}$ порівняно 3 мертвою фракцією і очосом відповідно. У 2017 р. вміст ${ }^{137} \mathrm{Cs}$ в очосі був в 1,3 та 1,4 раза вищий, ніж у живій та мертвій фракціях відповідно. Для мертвої та живої фракцій моху поглинання радіонуклідів було практичного однакове, проте для живої фракції відзначено вищі значення величин питомої активності радіонукліду. У 2018 р. вміст ${ }^{137} \mathrm{Cs}$ у живій фракції був в 1,2 раза менший, ніж в очосі, а останній містить ${ }^{137} \mathrm{Cs}$ в 1,3 рази більше, ніж мертва фракція. Для живої і мертвої фракцій простежуються подібні до попереднього року закономірності щодо накопичення. Упродовж 2016-2018 рр. спостерігалася загальна тенденція до зменшення величин питомої активності ${ }^{137} \mathrm{Cs}$ у кожній фракції плевроцію. Для очосу зменшення становило 1,2, а для живої і мертвої фракції - 1,3 раза. Достовірність отриманих результатів підтверджується дисперсійним аналізом: для живої фракції- $F_{\text {факт. }}=$ $7,0>F_{(2 ; 15 ; 0,95)}=3,7$; для мертвої фракції $-F_{\text {факт. }}=$ $8,9>F_{(2 ; 24 ; 0,95)}=3,4$; для очосу $-F_{\text {факт. }}=12,3>F_{(2 ; 33 ; 0,95)}$ $=3,3$.

Плевроцій Шребера та дикран багатоніжковий характеризуються високою інтенсивністю накопичення радіонуклідів, про шо свідчать високі величини розрахункових значень коефіцієнтів переходу до фітомаси мохів. Так, у 2016 р. інтенсивність надходження ${ }^{137} \mathrm{Cs}$ до фітомаси дикрану багатоніжкового становила $69^{ \pm 3,0} \mathrm{M}^{2} \cdot \kappa^{-1} \cdot 10^{-3}$, що у 1,3 рази вище порівняно 3 2017 р., а у 2018 р. величина коефіцієнта переходу у 1,6 і 1,2 рази менше, ніж у 2016 та 2017 рр. спостережень відповідно. Достовірність отриманих результатів підтверджується критерієм Фішера: 2016-2017 pp. $F_{\text {факт. }}=15,2>F_{(1 ; 53 ; 0,95)}=4,0 ; 2017-2018$ pp. $-F_{\text {факт. }}=$ $5,7>F_{(1 ; 48 ; 0,95)}=4,0 ; \quad 2016-2018$ pp. $-F_{\text {факт. }}=$ $46,1>F_{(1 ; 55 ; 0,95)}=4,0$. Стосовно плевроцію Шребера показники інтенсивності надходження радіонуклідів були такими: у 2016 р. $-47^{ \pm 2,0} \mathrm{M}^{2} \cdot \kappa \Gamma^{-1} \cdot 10^{-3}$, що в 1,3 раза більше порівняно з 2017 р. та в 1,5 раза - 32018 р., а для останнього величина коефіцієнта переходу в 1,2 раза менша, ніж у 2017 р. Загалом спостерігається тенденція до зниження значень коефіцієнта переходу на пробній площі для верхоплідного та бокоплідного моху. Треба зазначити, впродовж 2016-2018 рр. коефіцієнт переходу ${ }^{137} \mathrm{Cs}$ у фітомасу дикрану багатоніжкового характеризується в 1,4 раза вищими значеннями порівняно 3 плевроцієм Шребера. Достовірність отриманих результатів підтверджується критерієм Фішера: 2016-2017 рр. $-F_{\text {факт. }}=17,3>F_{(1 ; 40 ; 0,95)}=4,1 ; 2017-2018$ pp. $-F_{\text {факт. }}=$ $18,9>F_{(1 ; 44 ; 0,95)}=4,1 ; 2016-2018$ pp. $-F_{\text {факт. }}=$ $67,7>F_{(1 ; 42 ; 0,95)}=4,1$.

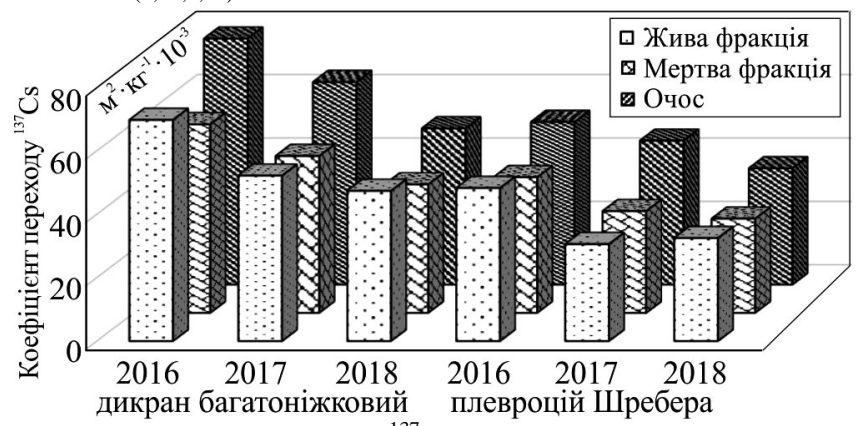

Рис. 2. Коефіцієнт переходу ${ }^{137} \mathrm{Cs}$ у різні фракції зелених мохів свіжого бору Українського Полісся у різні роки 
Під час аналізу інтенсивності надходження радіонукліду до різних фракцій моху з'ясовано, що для обох видів найвищі значення коефіцієнта переходу відзначено в очосі (рис. 2).

Джерело: результати отримали автори.

Так, у 2016 р. інтенсивність надходження ${ }^{137} \mathrm{Cs}$ до очосу дикрану багатоніжкового була вища в 1,2 і 1,6 раза, ніж у 2017 та 2018 рр., а для плевроцію - в 1,1 і 1,4 раза відповідно. Окрім цього у 2017 р. значення були вищими, ніж у 2018 р. - в 1,2 та 1,3 раза для плевроцію та дикрану відповідно. Достовірність різниці середніх значень коефіцієнта переходу до очосу підтверджується критерієм Фішера для дикрану та плевроцію за роками спостережень: 2016-2017 pp. $-F_{\text {факт. }}=$ $8,1>F_{(1 ; 17 ; 0,95)}=4,5$ та $F_{\text {факт. }}=5,9>F_{(1 ; 23 ; 0,95)}=4,3$; $2017-2018$ pp. $-F_{\text {факт. }}=12,3>F_{(1 ; 18 ; 0,95)}=4,4$ та $F_{\text {факт. }}=$ $12,9>F_{(1 ; 21 ; 0,95)}=4,3 ;$ та $2016-2018$ pp. $-F_{\text {факт. }}=$ $170,6>F_{(1 ; 18 ; 0,95)}=4,4$ та $F_{\text {факт. }}=74,3>F_{(1 ; 25 ; 0,95)}=4,2$. Мертва фракція дикрану у 2018 р. поглинала в 1,2 та 1,5 раза менше, ніж у 2017 та 2016 рp. $\left(F_{\text {факm. }}=\right.$ $14,2>F_{(1 ; 15 ; 0,95)}=4,6$ та $F_{\text {факт. }}=128,4>F_{(1 ; 14 ; 0,95)}=$ 4,7 відповідно), а у 2016 р. в 1,2 раза більше, ніж у 2017 p. $\left(F_{\text {факm. }}=16,5>F_{(1 ; 14 ; 0,95)}=4,7\right)$. Для плевроцію Шребера у 2016 р. інтенсивність надходження радіонукліду у мертву фракцію в 1,3 та 1,5 раза вища, ніж у 2017 та 2018 рр., а між останніми роками відзначено неістотну різницю середніх значень коефіцієнта переходу $\left(1,1\right.$ раза): $\quad F_{\text {факт. }}=42,5>F_{(1 ; 18 ; 0,95)}=4,4, \quad F_{\text {факт. }}=$ $52,3>F_{(1 ; 17 ; 0,95)}=4,5$ та $F_{\text {факт. }}=1,2<F_{(1 ; 16 ; 0,95)}=4,5$ відповідно.

Жива фракція плевроцію Шребера у 2016 р. мала коефіцієнти переходу ${ }^{137} \mathrm{Cs}$ в 1,6 та 1,5 раза вищі порівняно з 2017 та 2018 рр., а для дикрану така різниця відповідно становила 1,3 і 1,5 раза. Провівши однофакторний дисперсійний аналіз, встановлено, що між 2016-2017 та 2016-2018 pp. існує достовірна різниця щодо показника надходження ${ }^{137} \mathrm{Cs}$ у верхню фракцію для бокоплідного та верхоплідного моху відповідно: $F_{\text {факт. }}=$ $120,3>F_{(1 ; 11 ; 0,95)}=5,0$ та $F_{\text {факт. }}=25,7>F_{(1 ; 8 ; 0,95)}=5,6$; $F_{\text {daкm. }}=30,0>F_{(1 ; 12 ; 0,95)}=4,8$ та $F_{\text {qакт. }}=225,4>F_{(1 ; 9 ; 0,95)}$ $=5,3$. Перевищення інтенсивності надходження ${ }^{137} \mathrm{Cs}$ у живу фракцію обох видів моху в 2017 та 2018 рр. було неістотним $(1,1$ раза $)-F_{\text {факт. }}=0,3<F_{(1 ; 10 ; 0,95)}=5,1 \mathrm{Ta}$ $F_{\text {факт. }}=3,8<F_{(1 ; 10 ; 0,95)}=5,1$.

Основна кількість публікацій щодо радіоактивного забруднення представників мохового покриву припадає на 90-ті роки (Bolukh \& Virchenko 1994; Nifontova, 1995; Virchenko \& Bolyukh, 1993). Відзначено вищі значення питомої активності радіонукліду для дикрану багатоніжкового порівняно 3 плевроцієм Шребера (в 1,23,5 раза). Також зазначено, що з 1991 р по 1992 р. питома активність ${ }^{137} \mathrm{Cs}$ для дикрану зменшилася в $1,5-$ 3,0 раза, а для плевроцію - у 2-7 разів. Після 2000 р. була невелика кількість публікацій, у яких відсутні детальні дослідження специфіки накопичення та розподілу ${ }^{137} \mathrm{Cs}$ за фракціями зелених мохів, наведено лише загальні закономірності накопичення техногенних радіонуклідів моховим покривом (Gudzenko, 2007; Dragovic et. al. 2010). Грунтуючись на отриманих результатах досліджень можна стверджувати, що вивчення сучасного вмісту ${ }^{137} \mathrm{Cs}$ у фітомасі представників бокоплідних та верхоплідних мохів є необхідним та актуальним. Сучасний розподіл радіонуклідів у зелених мохах сприятиме розширенню уявлень про утримування ${ }^{137} \mathrm{Cs}$ у лісових екосистемах та обгрунтуванню використання цих видів у ролі біоіндикаторів радіоактивного забруднення лісових територій.

Висновки. Плевроцій Шребера характеризується в 1,5 раза меншими значеннями вмісту ${ }^{137} \mathrm{Cs}$ у фітомасі порівняно з дикраном багатоніжковим. Для дикрану та плевроцію характерний тотожний пофракційний розподіл ${ }^{137} \mathrm{Cs}$. Найвищі значення його питомої активності відзначено в очосі, а мінімальні - у мертвій фракції, жива фракція характеризується проміжними значеннями вмісту ${ }^{137} \mathrm{Cs}$. Упродовж 2016-2018 pp. середнє значення питомої активності ${ }^{137} \mathrm{Cs}$ в очосі моху верхоплідного та бокоплідного зменшилося відповідно в 1,4 і 1,2, а для живої та мертвої фракцій подібне зменшення становило 1,3 раза. 32016 по 2018 рр. інтенсивність надходження радіонуклідів до фітомаси зелених мохів істотно зменшилося і для дикрану воно становило 1,5, а для плевроцію - в 1,4 раза. Під час аналізу коефіцієнта переходу ${ }^{137} \mathrm{Cs}$ у фітомасу брієвих мохів відзначено, що у живій фракції дикрану та плевроцію інтенсивність надходження зменшилася в 1,5 раза, для мертвої фракції таке зменшення становило 1,5 та 1,4 , а для очосу1,6 та 1,4 раза відповідно.

\section{References}

Bolukh, V. A., \& Virchenko, V. M. (1994). The accumulation of radionuclides by the mosses of the Ukrainian Polesie. Ukrainian Botanical Journal, 4(51), 39-45. [In Ukrainian].

Bolukh, V. A. (1994). Radioecological monitoring of bryophytes. Ukrainian Botanical Journal, 2/3(51), 172-178. [In Ukrainian].

Dragovic, S., Mihailovic, N., \& Gajic, B. (2010). Quantification of transfer of ${ }^{238} \mathrm{U},{ }^{226} \mathrm{Ra},{ }^{232} \mathrm{Th},{ }^{40} \mathrm{~K}$ and ${ }^{137} \mathrm{Cs}$ in mosses of semi-narural ecosystem. Journal of Environmental Radioactivity, 2(101), $159-164$.

Grodzinsky, D. M. (1959). On the natural radioactivity of mosses and lichens. Ukrainian Botanical Journal, 2(16), 30-38. [In Ukrainian].

Gudzenko, V. V. (2007). Mosses as concentrators of some technogenic and cosmogenic radionuclides. Ecological chemistry, 16(2), 8590. [In Russian].

Kulikov, N. V., \& Bochenina, N. V. (1976). Features of accumulation of ${ }^{137} \mathrm{Cs}$ and ${ }^{90} \mathrm{Sr}$ by some types of mosses. Ecology, 6, 82-85. [In Russian].

Kulikov, N. V., \& Molchanova, I. V. (1990). Radioecology of land cover. Sverdlovsk: UrOANSSSR. [In Russian].

Melnyk, V. V., \& Kurbet, T. V. (2018). Features accumulation of cesium-137 by mossy layer of Ukrainian Polissia. Scientific horizons, 2(65), 51-57. [In Ukrainian].

Mokronosov, M. G., \& Kulikov, N. V. (1988). Radioecological study of natural ecosystems in the area of nuclear power plants. Ecology, 3, 40-45. [In Russian].

Molchanova, I. V., \& Bochenina, N. V. (1980). Mosses as storage of radionuclides. Ecology, 3, 42-47. [In Russian].

Nifontova, M. G. (1995). The content of long-lived radionuclides in the moss cover of the East Ural radioactive wake zone. Ecology, 4, 326-329. [In Russian].

Nifontova, M. G. (2006). Long-Term Dynamics of Technogenic Radionuclide Concentrations in Moss - Lichen cover. Russiun jornal of Ecology, 37(4), 247-250.

Popovic, M., Zaja, R., \& Smital, T. (2010). Organic anion transporting polypeptides (OATP) in zebrafish (Danio rerio): Phylogenetic analysis and tissue distribution. Biochem. Physiol. A Mol. Integr. Physiol, 155(3), 327-335.

Reimann, C., Flem, B., Arnoldussen, A., Englmaier, P., Finne, T., Koller, F., \& Nordgulen, Ø. (2008). The biosphere: A homogenizer of Pb-isotope signals. Applied Geochemistry, 4(23), 705-722.

Schröder, W., Pesch, R., Englert, C., Harmens, H., Suchara, I., Zechmeister, H. G., Thöni, L., Mankovská, B., Jeran Z., Grodzinska, K., \& Alber, R. (2008). Metal accumulation in mosses ac- 
ross national boundaries: Uncovering and ranking causes of spatial variation. Environmental Pollution, 151(2), 377-388.

Virchenko, V. M., \& Bolyukh, V. A. (1993). The accumulation of radionuclides by mosses in the phytocenoses of Ukrainian Polissya.
Thesei reporting to the Radiobiological Congress, (pp. 183-184). Pushchino. [In Russian].

V. V. Melnyk', T. V. Kurbet ${ }^{1}$, A. R. Maksymchuk ${ }^{1}$, O. V. Vysotskiy ${ }^{1}$, Z. M. Shelest ${ }^{1}$, I. V. Davydova ${ }^{1}$, O. V. Zborovska ${ }^{2}$

${ }^{I}$ Zhytomyr Polytechnic State University, Zhytomyr, Ukraine

${ }^{2}$ Poliskiy Branch of Ukrainian Research Institute of Forestry and Forest Melioration named after G. M. Vysotsky, Dovzhyk, Ukraine

\section{DYNAMICS OF RADIOACTIVE CONTAMINATION OF GREEN MOSSES} IN FRESH PINE FOREST OF ZYTOMYR POLISSYA

Moss cover is an important component of forest ecosystems, especially in pine forests. It serves as a barrier to the migration, redistribution and accumulation of ${ }^{137} \mathrm{Cs}$ in forest soils and other components of forest biogeocenoses. To study the dynamics of present radioactive contamination of moss cover on tested area, samples of 2 types of green mosses were taken from fresh pine forests during 2016-2018 studied period. The density of radioactive soil contamination within the tested area varied from 167 to $358 \mathrm{kBq} / \mathrm{m}^{2}$. Significant fluctuations in the specific activity values and ${ }^{137} \mathrm{Cs}$ intake intensities for the tested green moss species were revealed. The content of radionuclide in the phytomass of Dicranum polysetum Sw. decreased by 1.3 times during the studied period, and Pleurozium schreberi decreased by 1.2 times. Dicranum polysetum Sw. was found to be characterized by significantly higher values of the specific activity of ${ }^{137} \mathrm{Cs}$ in comparison with Pleurozium schreberi, on average by 1.5 times during the studied period. For two types of green mosses, identical regularity was observed regarding the distribution of ${ }^{137} \mathrm{Cs}$ content over fractions during the analyzed period. According to the magnitude of radioactive contamination, the moss fraction can be ranked in the following order: combings > live fraction> dead fraction. Overall, for the studied period (2016-2018), the average specific activity of ${ }^{137} \mathrm{Cs}$ in the combings of acrocarpous and pleurocarpic mosses decreased by 1.4 and 1.2 times, respectively, and for the live and dead fractions by 1.3 times. The intensity of radionuclide intake into the phytomass of Pleurozium schreberi is 1.4 times lower compared to Dicranum polysetum Sw. There is a tendency of decreasing values of the ${ }^{137} \mathrm{Cs}$ transition coefficient, both in the phytomass as a whole and in the individual fractions for both moss species under study. Thus, the intensity of radionuclide intake, from 2016 to 2018 studied periods, for the living fraction of Pleurozium schreberi and Dicranum polysetum Sw. decreased by 1.5 times, for the dead fraction by 1.4 times and for the combings - by 1.4-1.6 times respectively.

Keywords: specific activity; ${ }^{137} \mathrm{Cs}$; intensity of radionuclide intake; moss fractions. 